\section{The Archaeological Use of Landscape Treatment in Social, Economic, and Ideological Analyses}

\section{Symposium, 1987 Meeting of the Society for Historical Archaeology Conference on Historical and Underwater Archaeology Savannah, Georgia}

COMPILED By FAITH HaRrington DEPARTMENT OF ARCHAEOLOGY BOSTON UNIVERSITY

Boston, MassachusetTs 02215

\section{Introduction}

The following papers were presented at the 1987 Meeting of the Society for Historical Archaeology Conference on Historical and Underwater Archaeology in Savannah, Georgia. Faith Harrington organized the symposium in which these papers were presented, entitled "The Archaeological Use of Landscape Treatment in Social, Economic, and Ideological Analyses,' and compiled the papers for publication in Historical Archaeology.

The symposium explored the social, economic, and ideological ramifications of landscape treatments from the late 17th through the early 20th centuries. Ways in which people manipulated the natural and built environments in their yards, lots, farmsteads, factories, and eventually their cities were examined; how people manipulated landscapes to create, ensure, and reinforce their social and political relationships with others was also considered. The original six papers examined the contributions from various types of data-including architectural, archival, palynological, and macrofloral-and new methods of data recovery for understanding these phenomena. One of the main goals of the symposium was to examine archaeological data from individuals of divergent socioeconomic backgrounds and suggest possible class associations to landscape treatments. Additionally, the role of architectural elements (houses, additions to main houses, garden buildings, barns, agricultural facilities, outbuildings, corporate quarters, and workers' housing) as transformational devices was considered. Two examples of material expressions which indicate paradoxes between stated ideologies and material existences were explored also (see Beaudry's and Praetzellis and Praetzellis's papers). The presentation of all of the papers, and the publication of three of the papers, was enhanced by the comments of three individuals who have researched and considered issues in landscapes and ideology extensively: Mark Leone, William Kelso, and Patricia Rubertone. 